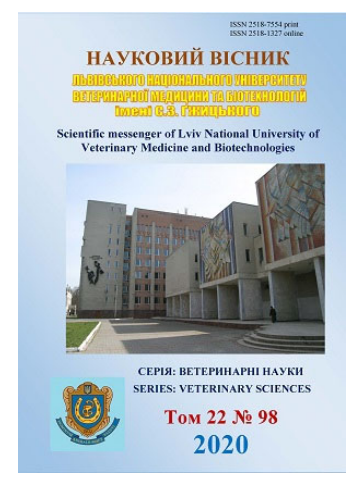

\author{
Науковий вісник Дьвівського націонадьного університету \\ ветеринарної медицини та біотехнологій імені С.3. Гжицького. \\ Серія: Ветеринарні науки \\ Scientific Messenger of Lviv National University \\ of Veterinary Medicine and Biotechnologies. \\ Series: Veterinary sciences
}

UDC 619:616-006.6:617-089.8:663.7

\title{
Clinical characteristics of mastocytoma in dogs
}

\author{
B. B. Ivashkiv, A. R. Mysak, V. V. Pritsak
}

Stepan Gzhytskyi National University of Veterinary Medicine and Biotechnologies Lviv, Ukraine

Article info

Received 30.04.2020 Received in revised form 01.06 .2020 Accepted 02.06.2020

Stepan Gzhytskyi National University of Veterinary Medicine and Biotechnologies, Pekarska Str., 50, Lviv, 79010, Ukraine. Tel.: +38-067-800-07-05 E-mail:mysak.andriy.sofia@gmail.com
Ivashkiv, B. B., Mysak, A. R., \& Pritsak, V. V. (2020). Clinical characteristics of mastocytoma in dogs. Scientific Messenger of Lviv National University of Veterinary Medicine and Biotechnologies. Series: Veterinary sciences, 22(98), 144-153. doi: 10.32718/nvlvet9825

According to foreign researchers, mastocytoma is one of the most common (7-12\%) skin tumors in dogs. This neoplasia is caused by excessive proliferation of mast cells and characterized by a specific clinical course, unpredictable biological behavior and prognosis. Researches of clinical and morphological features of mastocytoma in geographical populations of Ukraine has not only scientific and general biological interest, but also important practical significance. The purpose of the research was to establish the frequency of spreading, the features of the clinical ostent and pathogenesis of cutaneous mastocytoma in dogs in conditions in Lviv and in the suburban zone of the regional center. The research was performed on dogs with skin tumors $(n=128)$, including 24 of them with mastocytoma, who came to the Department of Surgery and Clinic of Small Pets of Stepan Gzhytskyj LNUVMB during 2016-2020. The diagnosis on mastocytoma was verified by the results of physical examination and cytological examination of biopsy material of neoplasms. It was found that in the structure of oncological diseases of dogs the share of skin neoplasms was $32.16 \%$. Among animals with skin neoplasms, mastocytoma was diagnosed in $18.75 \%$ of dogs aged 4 to 16 years. The highest incidence rates were found among animals aged 8 to 11 years; the median incidence was 9.5 years and fashion - 9 years. In terms of breeds, cutaneous mastocytoma was found in dogs of the breed: Rottweiler - $16.7 \%$, Sharpei - $12.5 \%$, Staffordshire Terrier - $12.5 \%$, Labrador $-8.3 \%$, Boxer $-8.3 \%$, Doberman - $8.3 \%$, chow-chow - $8.3 \%$. At the same time, the German Shepherd, Alabai, Spaniel, French Bulldog and Pug cases of the disease were isolated (4.2\%). Among sick animals, dogs accounted for $54.2 \%$ and females for $45.8 \%$. It was found that in $41.7 \%$ of the studied animals the rate of neoplasia was extremely rapid, because in $56.5 \pm 1.91$ days the tumors were doubled in size, which is evidence of significant aggressiveness of tumor growth. In $29.2 \%$ of dogs the time of doubling the size of the primary tumor reached $122.1 \pm 10.6$ days, in $20.8 \%$ of dogs the period of tumor development lasted for two years. In $8.3 \%$ of dogs, the dynamics of neoplasia development is not clear. Sonography has shown that skin mastocytomas are usually visualized as heterogeneous, with uneven edges and fuzzy contours hypoechoic structures. Visualization of solid hypervascular foci with central type of vascularization, on the background of diffuse infiltration of neoplasia in the deeper layers of the skin and subcutaneous tissue, with a pronounced perinodular inflammatory reaction of the surrounding tissues is a sign of malignancy of the mastocytoma. The generalization of the neoplastic process in the internal organs was found, in particular the spleen, may indicate a predominance of the hematogenous route of metastasis of the mastocytoma. The obtained data complement and expand knowledge about the pathogenesis of mastocytoma in dogs, and also highlight the frequency of spreading and course features of this oncological pathology in a separate geographical population of Ukraine.

Key words: dogs, skin tumors, mastocytoma, spread, cytological examination, clinical signs, sono and radiography.

\section{Клінічна характеристика мастоцитоми у собак}

\author{
Б. Б. Івашків, А. Р. Мисак, В. В. Пріцак
}

Львівський національний університет ветеринарної медицини та біотехнологій імені С. З. Гжищького, м. Львів, Україна 
Згідно повідомлень зарубіжних дослідників мастоцитома є однією з найбільш поширених (7-12\%) пухлин икіри у собак. Дана неоплазія обумовлена надмірною проліферацією опасистих клітин і характеризується специфічним клінічним перебігом, непередбачуваною біологічною поведінкою та прогнозом. Вивчення клініко-морфологічних особливостей мастоиитоми в географічних популяціях Украйни має не тільки науковий та загальнобіологічний інтерес, але й важливе практичне значення. Метою досліджень було встановлення частоти поширення, особливостей клінічного прояву та патогенезу шкірної форми мастоцитоми у собак в умовах м. Львів та в приміській зоні обласного иентру. Дослідження проводили на собаках з пухлинами шкіри (п = 128), в тому числі, 24 із них з масточитомою, які надходили на кафедру хірургї та клініку дрібних домашніх тварин ЛНУВМБ імені С. 3. Гжицького впродовж 2016-2020 рр. Діагноз на мастоцитому верифіковано за результатами фізикального обстеження та цитологічного дослідженя біопсійного матеріалу неоплазій. Встановлено, шчо у структурі онкологічних хвороб собак частка неоплазій шкіри становила 32,16\%. Серед тварин із неоплазіями шкіри мастоцитому діагностовано у 18,75 \% собак, віком від 4 до 16 років. Найвищі показники захворюваності встановлено поміж тварин віком від 8 до 11 років; при иьому медіана захворюваності становила 9,5 роки і мода - 9 років. У розрізі порід шкірну мастоцитому встановлено в собак породи: ротвейлер - 16,7\%, шарпей - 12,5\%, стафордширський тер'єр - 12,5\%, лабрадор - 8,3\%, боксер - 8,3\%, доберман - 8,3\%, чау-чау - 8,3\%. Водночас, у тварин породи німецька вівчарка, алабай, спанієль, франиузький бульдог, мопс випадки захворювання були поодинокими (4,2\%). Серед хворих тварин пси становили - 54,2 \%, суки - 45,8\%. 3'ясовано, шуо у 41,7 \% досліджуваних тварин швидкість розвитку неоплазій була надзвичайно стрімкою, оскільки за 56,5 $\pm 1,91$ діб пухлини подвоїли свою величину, щзо є свідченням значної агресивності пухлинного росту. У 29,2 \% собак час подвоєння величини первинної пухлини сягав 122,1 $\pm 10,6$ доби, в 20,8 \% собак період розвитку новоутворень тривав впродовж двох років. У 8,3 \% собак динаміка розвитку неоплазій не з'ясована. За результатами сонографії з'ясовано, щу мастоцитоми шкіри візуалізуються зазвичай як неоднорідні, з нерівними краями і нечіткими контурами гіпоехогенні структури. Візуалізація солідних гіперваскулярних вогнищ з центральним типом васкуляризації, на тлі дифузної інфільтрачї неоплазії в глибшележачі шари шкіри та підикірну клітковину, за вираженої перинодулярної запальної реакції навколишніх тканин є ознакою малігнізації мастоцитоми. Встановлена генералізація неопластичного процесу у внутрішні органи, зокрема селезінку, може свідчити про переважання гематогенного иляху метастазування мастоцитоми. Отримані дані доповнюють та розширюють знання щуодо патогенезу мастоцитоми у собак, а також висвітлюють частоту поширенння та особливості перебігу даної онкологічної патології в умовах окремої географічної популяції України.

Ключові слова: собаки, пухлини шкіри, мастоцитома, поширення, цитологічне дослідження, клінічні ознаки, соно та рентгенографія.

\section{Вступ}

Мастоцитома (Mast cell tumors, MCT, Mastocytoma) - неоплазійне захворювання різних видів тварин та людини обумовлене надмірною проліферацією мастоцитів - клітин мезенхімального походження, так званих mast cell (MC), син.: лаброцитів, тучних (ТК), опасистих клітин (ОК). Загальновідомо, що мастоцити є одними з основних клітинних форм, які регулюють в організмі ссавців гомеостаз сполучної тканини та виконують захисну функцію формування природженого імунітету. Зазвичай, висока концентрація цих клітин акумулюється навколо кровоносних і лімфатичних судин у тканинах, що мають постійний контакт із чинниками зовнішнього середовища, зокрема, в шкірі, слизових оболонках дихальних шляхів та шлунково-кишкового каналу. Відомо також, що мастоцити належать до високоактивних тканинних елементів здатних продукувати цілу низку біологічно активних речовин і медіаторів (гістамін, гепарин, серотонін, хондроїтинсульфати, гіауронова кислота, протеази, глікопротеїни, фактор некрозу пухлин- $\alpha$ (TNF- $\alpha)$, хемотаксичний фактор міграції еозинофілів, інтерлейкіни (IL) $1,-2,-3,-4,-5,-6$ та ін.) та депонувати їх у гранулах цитоплазми. Окрім цього на своїй поверхні ОК містять специфічні IgE-антитіла, відповідальні за розвиток алергічних реакцій. Водночас, активація та дегрануляція мастоцитів супроводжується вивільненням біологічно активних речовин, що відіграє одну із провідних ролей в ініціюванні та перебігу як фізіологічних, так і патологічних процесів. Результати сучасних наукових досліджень (Hsu \& Boyce, 2009; Valent et al., 2012; Bautista-Quach et al., 2013; Akin, 2020) засвідчують, що синдром активації мастоцитів (САM), є досить поширеним розладом у патогенезі як для дуже рідкісних, так і поширених захворювань. При цьому відмічено, що кількість ОК суттєво збільшується при імунних реакціях і запаленні. Відповідно до сучасного трактування у гуманній медицині (Akin et al., 2010; Alvarez-Twose et al., 2016; Okhotnikova et al., 2018) САМ, обумовлений вивільненням медіаторів з активованих мастоцитів, об'єднує гетерогенну групу захворювань, які характеризуються клінічними ознаками ураження шкіри, слизових оболонок шлунково-кишкового тракту і дихальних шляхів, органів серцево-судинної та нервової систем, у тому числі й системними реакціями, зокрема, алергі$€ ю$ та анафілаксією. Як свідчить аналіз літературних повідомлень (Willmann et al., 2018; Tamlin et al., 2020) перебіг захворювань, за безпосередньої участі активованих ОК, у людини та в тварин має певні відмінності. За даними медичної літератури (Frieri \& Quershi, 2013; Valent et al., 2015; Gülen et al., 2016; Pardanani, 2016; Frolova et al., 2018; Leguit et al., 2020) на мастоцитоз частіше хворіють діти у яких хвороба перебігає у шкірній формі (зазвичай, як пігментна кропив'янка, рідше солітарна мастоцитома) і при досягненні пубертатного віку хвороба, як правило, регресує. Водночас, серед дорослих доброякісні форми мастоцитозу трапляються рідко. Як правило, дорослі, незалежно від статі, хворіють системним мастоцитозом, який проявляться ураженням не лише шкіри, а й кісткового мозку, печінки, слезінки та інших органів, при цьому хвороба має надзвичайно агресивний перебіг, несприятливий прогноз та короткий період виживаності за лікування. Згідно повідомлень вище вказаних дослідників значна варіабільність мастоцитозу на сьогодні створює труднощі як за встановлення діагнозу та ідентифікації хвороби, так і при призначенні адекватного лікування.

На підставі даних багаторічного вивчення мастоцитозу за ініціативи Всесвітньої організації охорони 
здоров'я (ВООЗ) у 2016 році сформовано клінічну класифікацію (Hartmann et al., 2016; Valent et al., 2017), відповідно до якої асигнують шкірний мастоцитоз, системний мастоцитоз та локалізовані пухлини ОК. За деталізації класифікаційної характеристики захворювання, зокрема, за шкірного мастоцитозу (Cutaneous mastocytosis (CM)), виділяють три підтипи: пігментну кропив'янку (Urticaria pigmentosa (UP)) або макуло-папульозний мастоцитоз ((Maculo-papular cutaneous mastocytosis (MPCM)) - мономорфний та поліморфний тип, дифузний шкірний мастоцитоз (Diffuse cutaneous mastocytosis (DCM)) та солітарну мастоцитому шкіри (Solitary mastocytoma of skin (SMS)). При системному мастоцитозі (Systemic mastocytosis (SM)) виокремлюють: індолентний (уповільнений) системний мастоцитоз (Indolent systemic mastocytosis (ISM)), системний мастоцитоз, асоційований з гематологічним захворюванням (не з опасистих клітин) (Systemic mastocytosis with associated clonal haematological non-mast cell lineage diseases (SM-AHNMD)), агресивний системний мастоцитоз (Aggressive systemic mastocytosis (ASM)), лейкемія 3 опасистих клітин (Mast cells leukemia (MCL)), саркома опасистих клітин (Mast cells sarcoma (MCS)), позашкірна мастоцитома (Extracutaneous mastocytoma (ЕСM)). Відповідно до чинної класифікації клінічний перебіг захворювання дуже варіабельний, що обумовлює потребу наукового пошуку як новітніх діагностичних маркерів, так і розробки нових удосконалених лікувальних заходів. Безперечно, на сьогодні мастоцитоз i, зокрема, гетерогенні пухлинні та системні прояви хвороби залишається однією із актуальних проблем не лише сучасної гуманної медицини, а й ветеринарії.

За даними зарубіжної літератури (Misdorp, 2004; Blackwood, 2011; Villamil et al., 2011; Lisickaja \& Sedov, 2011; Blackwood et al., 2012; Garrett, 2014; Sledge et al., 2016) найбільш характерною патологією, що обумовлена проліферацією атипових поліморфних ОК у тварин є неоплазія шкіри - мастоцитома, а також системний мастоцитоз, у випадках ураження внутрішніх органів та кісткового мозку. Діагностується дане захворювання у різних видів тварин, проте найчастіше трапляється у собак, рідше у великої рогатої худоби, коней, котів. Згідно повідомлень вище вказаних дослідників мастоцитома (Mast cell tumors (MCTs)) у собак займає 7-21\% від усіх пухлин шкіри і вважається для даного виду тварин однією не лише 3 найбільш поширених, а й з найбільш непередбачуваних онкологічних хвороб щодо клінічного перебігу, біологічної поведінки та прогнозу.

Належно відмітити також, що спонтанні пухлини тварин відповідають багатьом критеріям новоутворень людини, а схожість етіології, патогенезу, симптоматики та морфології пухлин у собак і людини обумовлює використання тварин, як моделей для вивчення біології пухлинного процесу та розробки сучасних діагностичних і терапевтичних заходів (Willmann et al., 2018; Garden et al., 2018; Gargiulo, 2018).

Слід зазначити, що незважаючи на значну кіль- кість зарубіжних робіт, присвячених вивченню мастоцитоми, вітчизняні науковці та практикуючі лікарі ветеринарної медицини даному захворюванню не приділяють належної уваги. Так, аналіз вітчизняних публікацій що висвітлюють проблеми онкологічної патології тварин в Україні і передусім дослідження неоплазій шкіри, показав, що за останні роки опубліковано лише декілька робіт (Mysak, 2012; Zon et al., 2013; Mykhailenko \& Voitsekhovych, 2017; Lieshchova et al., 2018; Ivashkiv et al., 2019) у яких подано інформацію щодо частоти поширення новоутворень шкіри їх нозології та структури залежно від породи, статі та віку тварин. Водночас, у доступній літературі немає жодної публікації присвяченої вивченню МСТs. Цілком зрозуміло, що відсутність наукового інформаційного забезпечення негативно віддзеркалюється на діагностуванні та лікуванні онкологічно хворих тварин. Так, нерідко, з причини необізнаності практикуючих лікарів із клініко-морфологічними особливостями прояву неоплазій, а також за відсутності кваліфікованого патоморфологічного дослідження виникають проблеми щодо верифікації мастоцитоми та встановлення ступеня іiі злоякісності. У таких випадких виявлену неоплазію ідентифікують, зазвичай, як “пухлину шкіри”, а лікувальні заходи обмежуються лише хірургічним видаленням пухлини. Проте, таке лікування за повідмленнями практикуючих лікарів ветеринарної медицини не завжди є ефективним.

Вочевидь, вище наведена інформація є мотивованим обгрунтуванням для проведення в умовах України в цілому та в різних географічних популяціях зокрема різнопланових досліджень щодо вивчення шкірної мастоцитоми собак, а також виявлення інших захворювань спричинених надмірною проліферацією ОК. Виходячи $з$ цього метою досліджень було встановити частоту поширення, особливості клінічного прояву та патогенезу шкірної форми мастоцитоми у собак в умовах м. Львів та в приміській зоні обласного центру.

\section{Матеріал і методи досліджень}

Дослідження проводили на кафедрі хірургії та клініці дрібних домашніх тварин ЛНУВМБ імені С. 3. Гжицького впродовж 2016-2020рp. Об'єктом досліджень були 128 собак з пухлинами шкіри, в тому числі, 24 із них з мастоцитомою. Тварини були різних порід і статі, віком від 4 до 16 років. Обстеження онкологічно хворих собак здійснювали згідно критеріїв клінічної (TNM) класифікації пухлин (Owen, 1980) використовуючи клінічні, інструментальні та лабораторні методи досліджень.

Ультрасонографію та рентгенографію використовували у собак як у цілях верифікації діагнозу, так і для оцінки перебігу пухлинної патології у динаміці. Ультразвукове дослідження виконували приладом “ESAOTE MyLab 40” за використання мультичастотного лінійного та конвексного датчиків у В-режимі при частоті 5,0 - 7,5 та 15 мГц на різних глибинах. Сонографічному дослідженню піддавались: безпосередньо сама неоплазія і навколишні тканини, регіонарні лім- 
фатичні вузли, а також, з метою виявлення віддалених метастазів, органи черевної і тазової порожнин. Одержане сонографічне зображення зберігали на цифрових носіях та аналізували ехоструктуру досліджуваних об'єктів. Під контролем сонографії проводили також тонкоголкову пункційну біопсію неоплазій 3 метою відбору матеріалу для цитологічного дослідження.

Рентгенографію ділянки пухлинного ураження, черевної порожнини, та грудної клітки, а при потребі й інших частин тіла тварин проводили за використання цифрового рентгенапарата "ZooMax LC" у двох стандартних взаємно перпендикулярних проекціях (прямій i боковій). Експозицію, напругу струму на трубці та фокусну відстань при рентгенографії вибирали за індивідуальними параметрами для кожної тварини залежно від маси ії тіла.

Морфологічну верифікацію неоплазій проводили за результатами цитологічного дослідження. Відбір матеріалу з пухлиноподібних утворень шкіри та регіонарних лімфатичних вузлів здійснювали шляхом прицільної біопсії під контролем УЗД за використання тонкоголкової та трепан-біопсії напівавтоматичними голками гільотинного типу Spring Cut 14G. За проведення пункційних маніпуляцій усі тварини піддавалися седації ксилазином в дозі 0,1 мл/кг маси тіла тварини. Мазки підсушували на повітрі, фіксували метиловим спиртом впродовж 5 хвилин, фарбували за Романовським-Гімза та вивчали під мікроскопом, використовуючи імерсійну систему. Критерієм для верифікації мастоцитоми було виявлення в цитологічних препаратах гомологічних круглих пухлинних клітин із азурофільними гранулами в цитоплазмі.

\section{Результати та їх обговорення}

За період 2016-2020 рр. в клініки кафедри хірургії i хвороб дрібних тварин ЛНУВМБ імені С. 3. Гжицького поступило 2905 собак із хірургічною патологією. Показник превалентності онкологічних захворювань серед досліджуваних тварин становив, в середньому 13,7 \% (табл. 1).

\section{Таблиця 1}

Превалентність онкологічних захворювань собак у розрізі 2016-2020 pp.

\begin{tabular}{|c|c|c|c|c|}
\hline \multirow{2}{*}{\multicolumn{2}{|c|}{ Показники }} & \multirow{2}{*}{$\begin{array}{c}\text { Обстежено собак } \\
\text { з хірургічною } \\
\text { патологією }\end{array}$} & \multicolumn{2}{|c|}{$\begin{array}{c}\text { Виявлено онкологічно } \\
\text { хворих }\end{array}$} \\
\hline & & & кількість голів & $\%$ \\
\hline \multirow{5}{*}{$\begin{array}{l}5 \\
0 \\
0\end{array}$} & 2016 & 492 & 52 & 10,56 \\
\hline & 2017 & 529 & 79 & 14,93 \\
\hline & 2018 & 581 & 86 & 14,8 \\
\hline & 2019 & 671 & 96 & 14,3 \\
\hline & 2020 & 632 & 85 & 13,44 \\
\hline \multicolumn{2}{|c|}{ Всього } & 2905 & 398 & 13,7 \\
\hline
\end{tabular}

Встановлено також, що серед загальної кількості онкологічно хворих тварин $(\mathrm{n}=398)$ у $128(32,16 \%)$ собак діагностовано пухлини та пухлиноподібні ураження шкіри. За результатами фізикального обстеження таких тварин, а також на підставі даних цитологічного дослідження біопсійних пунктатів неопла- зій у 24 (18,75 \%) собак встановлено діагноз - мастоцитома шкіри.

Згідно аналізу реєстраційних даних хворі на MCTs тварини були різних порід і статі, віком від 4 до 16 років. Зокрема, у розрізі порід шкірну мастоцитому встановлено в собак породи: ротвейлер - 4 випадки $(16,7 \%)$, шарпей - $3(12,5 \%)$, стафордширський тер'єр - 3 (12,5\%), лабрадор - 2 (8,3\%), боксер - 2 $(8,3 \%)$, доберман $2(8,3 \%)$, чау-чау - $2(8,3 \%)$. Водночас, у тварин породи німецька вівчарка, алабай, спанієль, мопс, французький та англійський бульдог, випадки захворювання були поодинокими (4,2 \%). Серед хворих тварин самці становили - 54,2 \%, самки - 45,8 \% (13 псів і 11 сук).

У віковому аспекті кількість випадків захворювання на MCTs розподілилася наступним чином: тварини віком 4 роки - 1 випадок (4,16 \%); відповідно 56 років - $2(8,33 \%) ; 7-8$ років - $5(20,83 \%) ; 9-10-9$ (37,5\%); 11-12 - 4 (16,7\%); 13-14 - 1 (4,16\%); старші 15 років - 2 (8,33 \%). При цьому найвищі показники захворюваності встановлено поміж тварин віком від 8 до 11 років, медіана захворюваності становила 9,5 роки, а мода (найбільша кількість хворих тварин) припадала на вік 9 років.

Слід зауважити, що декларовані нами результати статистичних досліджень асоціюються в цілому із данними зарубіжних повідомлень. Так, показники захворюваності собак на MCTs $(18,75 \%$ ), а також медіана (9,5 роки) і мода (9 років) $є$ рівнозначними із лімітними даними (відповідно, 7-21\%; 7-9 років; 910 років) встановленими іншими дослідниками (Misdorp, 2004; Murphy et al., 2006; Blackwood, 2011; Villamil et al., 2011; Sledge et al., 2016; Smiech et al., 2018). Згідно літературних даних (Dobson, 2013; Shoop-Worrall et al., 2015; Smiech et al., 2018) найвищий ризик розвитку MCTs характерний для собак таких порід як: боксер, американський стаффордширський тер'єр, лабрадор ретрівер, бостонський тер'єр, бігль, английский та французький бульдоги, шар-пей, мопс. Проте, як засвідчують наші дані, поряд із вище перечисленими породами, високі показники захворюваності (12,5-17 \%), можуть траплятися і серед собак інших порід, закрема ротвейлер, доберман, чау-чау. Встановлено також захворювання MCTs у німецької вівчарки, алабая, кокер-спанієля. Очевидно такі розбіжності із данними літератури можна пояснити прерогативою поширення тварин тих чи інших порід в різних географічних популяціях.

На сьогодні у клінічній практиці мастоцитому розглядають як неоплазію шкіри із специфічним клінічним перебігом, непередбачуваною біологічною поведінкою та прогнозом. Тому, преорітетність у наших дослідженнях була спрямована на з'ясування прогностичних чинників хвороби.

Результати фізикального обстеження собак при поступленні у клініку та спостережень вродовж діагностично-лікувального періду засвічили значну поліморфність зовнішнього вигляду і клінічного прояву MCTs. Зокрема, у досліджуваних собак траплялися неоплазії які мали вигляд: невеликих щільних вузликів (рис. 1); вузлів величиною 3-5 см, зазвичай, схо- 
жих на ліпому (рис. 2); гіганських пухлин величиною 10 см та більше (рис. 3); в окремих собак траплялися екземоподібні ураження шкіри схожі на нодулярний панікуліт (рис. 6). Встановлено, що у 22 (91,7 \%) собак мастоцитоми були поодинокими i лише у 2 $(8,3 \%)$ випадках - множинні. Найбільш частим місцем локалізації мастоцитоми були: тулуб (45,8 \%), кінцівки (37,5\%), рідше голова і шия, пахвова, пахвинна та промежинно-перианальна ділянки (16,7 \%).

Встановлено, що невеликі новоутворення (до 3 см), як правило, розміщувалися в товщі шкіри і були у вигляді добре відмежованого, рухомого пухлинного вузла округлої або еліпсоподібної форми (рис. 1). Відмічено також, що на початкових етапах розвитку, в окремих тварин мастоцитома проявлялася лише як слабо контуроване вузлувате ущільненя в товщі шкіри, на основі якого, з перебігом певного часу, формувався окремий пухлининий вузол.

На підставі анамнестичних даних та результатів власних спостережень встановлено, що у 10 (41,7 \%) досліджуваних тварин швидкість розвитку неоплазій була надзвичайно стрімкою, оскільки за $56,5 \pm 1,91$ діб пухлини подвоїли свою величину. Тобто впродовж 6-8 тижнів 3 невеликих вузликів чи ущільнень формувалися пухлини діаметром 5 см (рис. 2) і навіть більше, що є свідченням значної агресивності пухлинного росту. Досить швидким був ріст неоплазій у 7 (29,2 \%) собак, в яких час подвоєння величини первинної пухлини сягав, в середньому, чотири місяці $(122,1 \pm 10,6$ доби). Водночас, за даними анамнезу 3'ясовано, що в 5 (20,8 \%) собак період розвитку новоутворень тривав впродовж двох років.Інформація щодо розвитку пухлин у 2 (8,3\%) інших собак на час проведення дослідження була невідомою. Таким чином, можна вважати, що швидкість подвоєння пухлинної маси неоплазії є одним із клінічних прогностичних чинників при оцінюванні мастоцитоми.

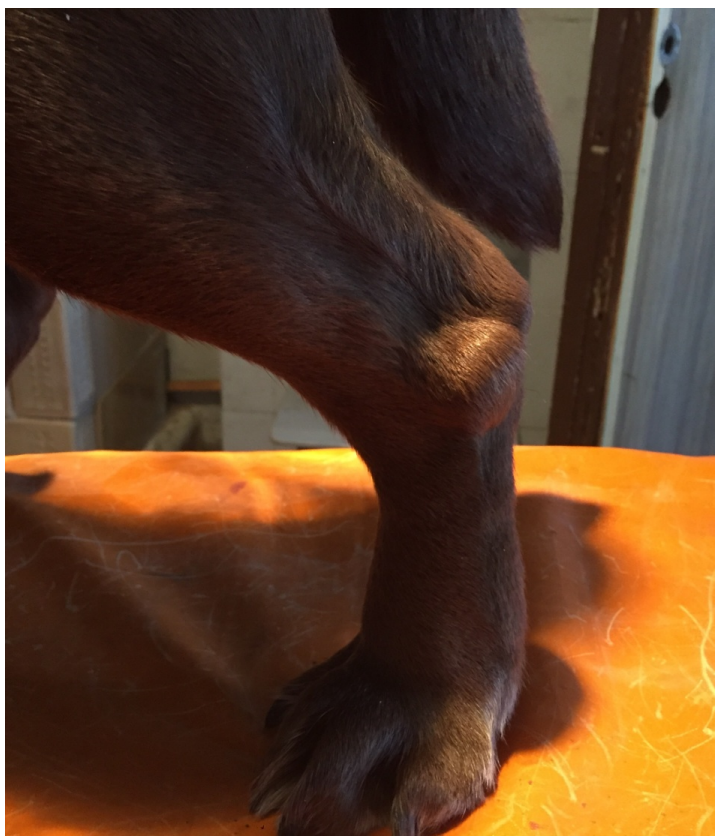

Рис. 1. Пес породи лабрадор, вік 8 років. Мастоцитома в ділянці задньої лапи

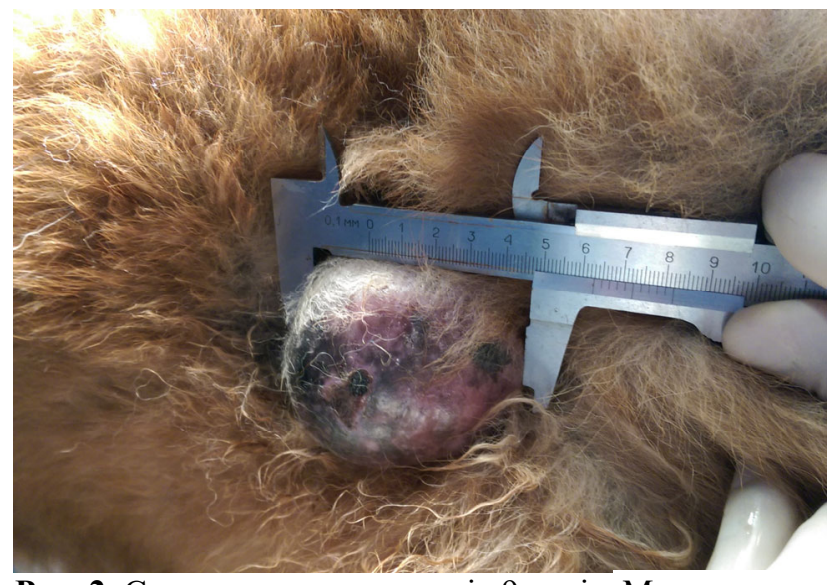

Рис. 2. Сука породи чау-чау, вік 9 років. Мастоцитома в ділянці тулуба (величиною 6,2х4,7 см, з виразковими дефектами у зоні пухлини та багряно-синюшним відтінком шкіри)

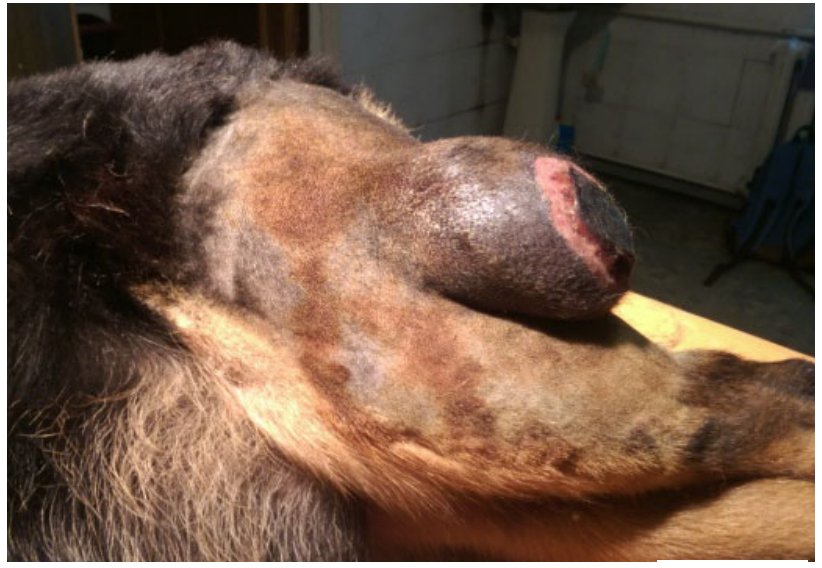

Рис. 3. Пес породи ротвейлер, вік 10 років. Гіганська мастоцитома в ділянці стегна

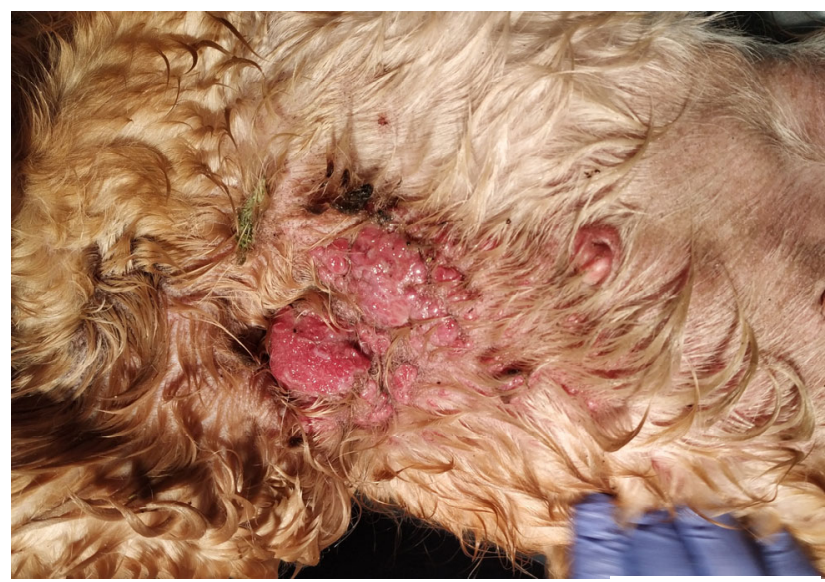

Рис. 4. Пес породи спанієль, вік 9 років. Мастоцитома в ділянці лівої пахвової ділянки та грудної клітки

Результати дослідження місцевого процесу та дані спостережень за перебігом хвороби засвідчили значну варіабельність клінічного прояву MCTs. Так, при пальпації неоплазії були м'якої (на початковому періоді розвитку), а з перебігом часу, щільно-еластичної консистенції, з гладкою або горбистою поверхнею. У понад 87 \% випадках характерними ознаками мастоцитоми були: набряк та запалення як у самій пухлині, 
так і в навколишніх тканинах (рис. 5), алопеція над пухлиною, еритема та наявність виразок шкіри (рис. 2, 3), періодична флуктуація величини пухлинного вузла, болючість при пальпації.

Відмічено також, що окрім болю для МСТs характерним був свербіж шкіри в ділянці пухлини, спричинений вивільненням ОК біологічно активних речовин, зокрема, гістаміну. 3 цієї причини собаки постійно лизали (рис. 6), дряпали і навіть гризли пухлину, провокуючи тим її подразнення і ріст.

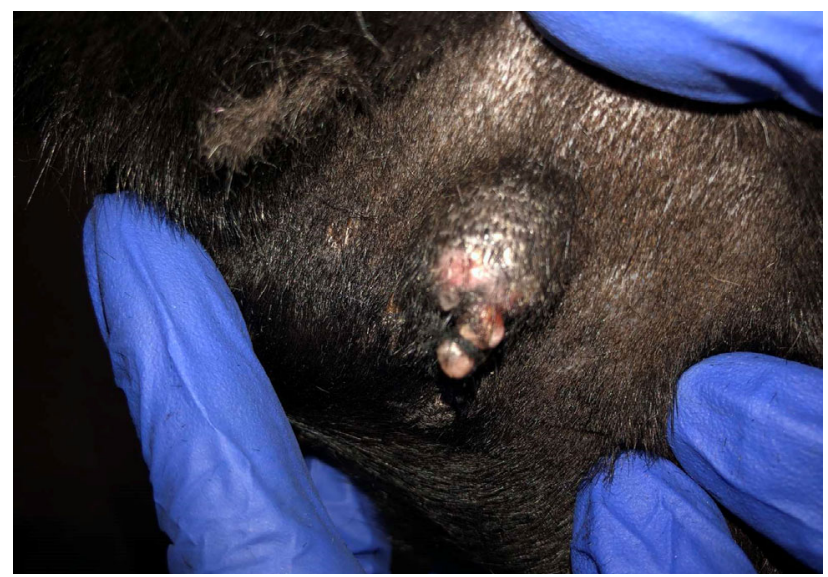

Рис. 5. Пес породи лабрадор, вік 7 років. Поганоконтурована мастоцитома в середній третині бокової поверхні шиї (виразки та рубці поверхні пухлини, нябряк і запалення навколишніх тканин)

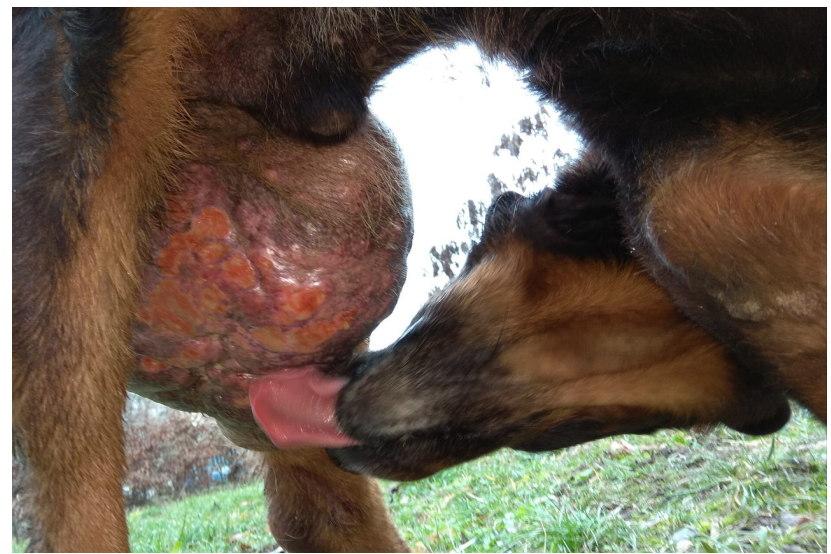

Рис. 6. Пес породи ротвейлер, вік 10 років.

Гіганська мастоцитома в ділянці колінного суглобу та ураження підколінного лімфатичного вузла

Результати спостережень засвідчили, що постійне подразнення та травмування пухлин було одним із чинників періодичного чи постійного загострення набряково-запального процесу, утворення виразок та, відповідно, швидкого росту неоплазій. Слід відмітити, що такий стрімко прогресуючий перебіг захворювання нами встановлено за локалізації мастоцитом на тазових кінцівках, в ділянках пахвини, промежини, шиї.

Важливими показниками, що можуть свідчити про злоякісніть MCTs є iї величина, швидкість росту, а також ступінь проростання в навколишні тканини, насамперед, ураження регіонарних лімфатичних вузлів та поширення (метастазування) у внутрішні орга- ни (Blackwood et al., 2012; Weishaar et al., 2014; Beer et al., 2018). Тому, в процесі клінічного обстеження увагу звертали на підщелепні, пахвові (аксілярні), поверхневі пахвинні, підколінні, а за потреби й інші регіонарні лімфатичні вузли.

За результатими первинного обстеження 24 собак у $11(45,8 \%)$ із них суттєвих змін зі сторони лімфатичних вузлів не виявлено, останні практично не пропальповувалися, що свідчило про відсутність їхньої реакції на патологічний процес. У 8 (33,3 \%) собак регіонарні лімфатичні вузли дещо збільшенні, проте не болючі, рухливі, не ущільнені, із гладкою поверхнею. Водночас у 5 (20,8 \%) собак із пухлинами великих розмірів (більше $10 \mathrm{~cm}$ в діаметрі) лімфатичні вузли були величиною 2-3 см, малорухомі, щільної косистенції. У однієї із цих тварин пальпація регіонарного лімфатичного вузла була досить ускладненою через зростання та фіксацію його до навколишніх тканин. Таким чином, результати дослідження собак iз мастоцитомами великих розмірів вказувати на генералізацію патологічного процесу в лімфатичні вузли.

Встановлені особливості клінічного прояву мастоцитоми надзвичайно важливі за розпізнавання даної неоплазії поміж багатьох інших пухлинних і не пухлинних уражень шкіри (гістиоцитома, ліпома, шкірна лімфома, карцинома сальних залоз, гранульма, нодулярний панікуліт, хронічне запалення шкіри та ін.).

Згідно міжнародної клінічної ТNM класифікації пухлин схема обстеження тварин за онкологічних захворювань передбачає проведення клінічного дослідження у комплексі з променевою діагностикою. Однак, на сьогодні у доступній вітчизняній літературі не завжди можна віднайти достатній об'єм інформації щодо застосування рентгено- та ультрасонографічного методів досліджень, та, відповідно, їх результативності за диференційної діагностики окремих патології шкіри у собак, в тому числі й неоплазій. Зважаючи на це, кожна із досліджуваних собак піддавалася рентгено- та ультразвуковому дослідженню як при поступленні у клініку, так і через певні проміжки часу, що дозволило прослідкувати динаміку патологічних процесів і поведінку пухлин. За результатами досліджень мастоцитом встановлено три типи росту i, відповідно, різновиди ознак, що характеризували обмежено вузловий, інфільтративно вузловий та дифузно інфільтративний типи рентгенологічної візуалізації таких неоплазій. Як показав аналіз рентгенограм, для обмежено вузлового росту властива гомогенна, рідше неоднорідна рентгенологічна тінь пухлинного вузла округлої або овальної форми, яка розміщена в товщі шкіри. У випадках інфільтративно вузлових пухлин візуалізувалися тіні пухлини без чітких контурів, при цьому структурні зміни були вираженими як у товщі шкіри, так і в підшкірній клітковині. При дифузно інфільтративному типі росту пухлин рентгенологічна тінь новоутворень ущільнена. Через потовщення шкіри, а також набряк та розшарування підшкірної клітковини встановити чітку межу новоутворення неможливо. Рентгенографічна тінь такої мастоцитоми виглядає за об'ємом значно меншою від іiі фактичної 
величини, встановленої за фізікального обстеження. Аналіз динаміки росту мастоцитом показав, що інфільтративно вузловий та дифузно інфільтративний типи рентгенологічної візуалізації неоплазій характеризують процес їх малігнізації.

За проведення рентгенографічного обстеження органів грудної та черевної порожнин у досліджуваних собак при поступленні в клініку чітко виражених ренгенологічних змін тканин, що могли вказувати на метастазування первинної пухлини у внутрішні органи не виявлено. Проте, за результатами моніторингу динаміки захворювання в однієї собаки на 183 добу спостереження встановлено позитивно-сумнівне ренгенографічне зображення, що могло свідчити про метастазування мастоцитоми в органи черевної порожнини, зокрема, селезінку. Тому основна увага за досліджень акцентована на результат УЗД ділянки локалізації неоплазії та внутрішніх органів.

Встановлено, що сонографічна структура мастоцитом залежить від стадії неопластичного процесу, місця локалізації та ступеня поширення патологічного процесу. Зазвичай мастоцитоми, які локалізувалися в товщі дерми мали вигляд неоднорідних, 3 нерівними краями і нечіткими контурами, переважно, гіпоехогенних структур. Ознаки інфільтрації навколишніх тканин свідчили про низьку тенденцію таких пухлин до капсулоутворення та поширення в глибшележачі шари шкіри. Сонографічні дослідження пухлин в динаміці показали, що для більшості мастоцитом характерною була дифузна кистозна дегенерація, що сонографічно візуалізувалася комірчастими утвореннями 3 перегородками та анехогенним вмістом (рис. 8). 3 перебігом часу такі утворення зливалися в одну солідно-кістозну структуру 3 ексцентричним вузловим гіпоехогенним компонентом, що був оточений анехогенною рідиною (рис. 7). Посилена периферична васкуляризація мастоцитоми та гіпоехогенна дифузна інфільтрація прилеглих тканин в таких випадках були ознакою запального набряку перинеопластичного компоненту (рис. 7).

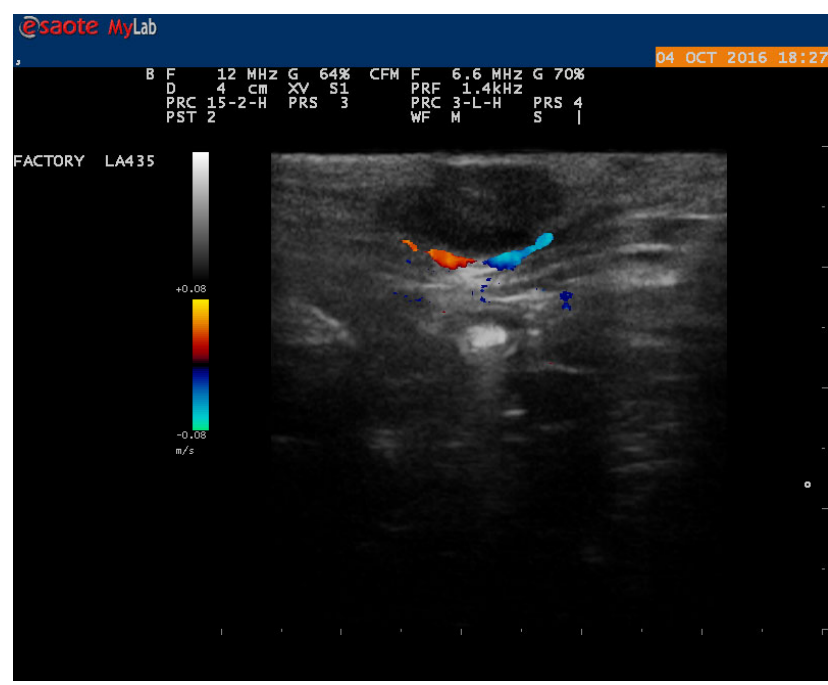

Рис. 7. Локалізація мастоцитоми в дермальному шарі. Периферична васкуляризація псевдокисти
За проведенння сонографічних досліджень окремих мастоцитом, що характеризувалися постійно превалюючим запаленням, у товщі неоплазії відмічено відкладення солей кальцію. Мікро- та макрокальцинати в товщі тканин (рис. 8), мали вигляд гіперехогенного тінеутворюючого вузлового утворення без ознак інтранодулярної васкуляризації.

Як показав аналіз результатів сонографічних досліджень найбільш виражені ознаки малігнізації неоплазій встановлено у випадках поширення мастоцитоми в глибшележачі шари шкіри та інфільтрації в підшкірну клітковину. За таких умов неопластичний процес набував вигляду солідного гіперваскулярного вогнища 3 центральним типом васкуляризації, яка була переважно хаотичною, з великою кількістю анастомозуючих ділянок 3 турбулентним потоком (рис. 9). Утворення таких вогнищ вказувало на високоактивну фазу неопластичного процесу, тобто інтенсивний його ріст на тлі дифузної інфільтрації прилеглих тканин та вираженої запальної реакції.

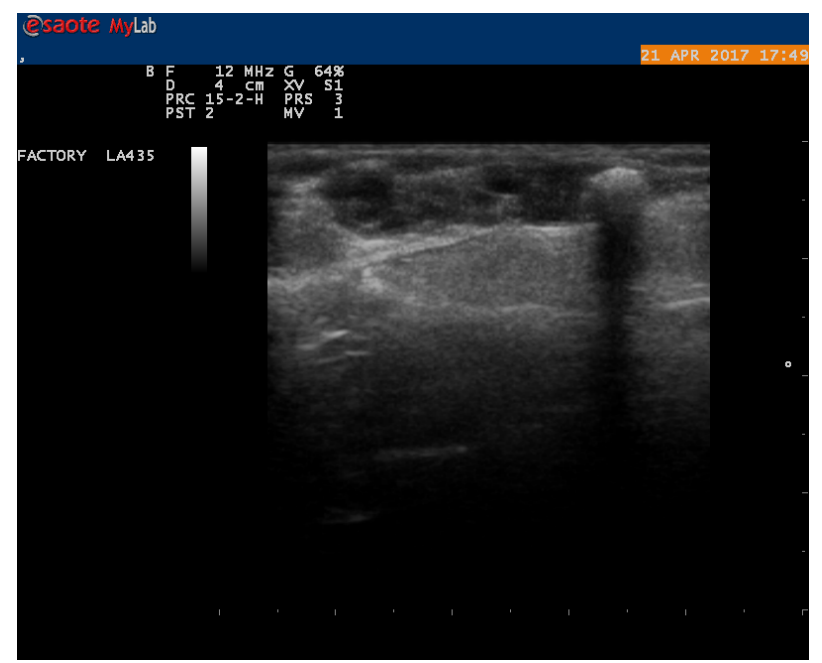

Рис. 8. Локалізація мастоцитоми в дермальному шарі. Наявність макрокальцинату в пухлинній тканині

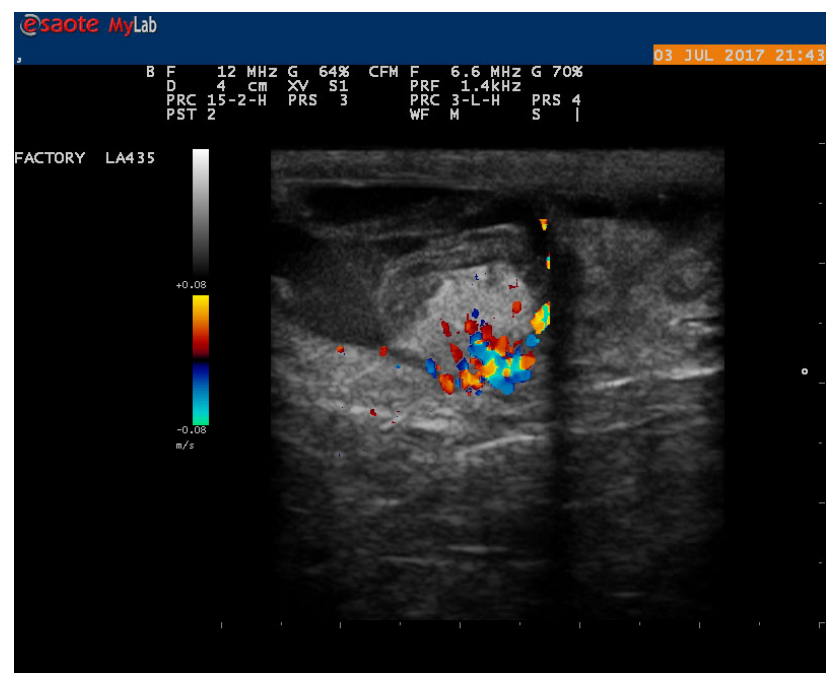

Рис. 9. Простання мастоцитоми в підшкірну клітковину. Солідне гіперваскулярне вогнище неоплазії. Перинеопластичний набряк 
За генералізації неопластичного процесу та поширенні мастоцитоми у внутрішні органи, вторинних уражень зазнавали селезінка та печінка, що може свідчити про переважання гематогенного шляху метастазування мастоцитоми. Сонографічно вогнища у внутрішніх органах мали схожу між собою стуктуру i візуалізувалися у вигляді щільних неоднорідних утворень $з$ чіткими контурами та нерівними краями, які мали посилену хаотичну васкуляризацію з ознаками турбулентного кровотоку, а також високу тенденцію до псевдокистозної та некротичної дегенерації, про що свідчила присутність в пухлинній тканині множинних осередків різного розміру з анехогенним вмістом (рис. 10).

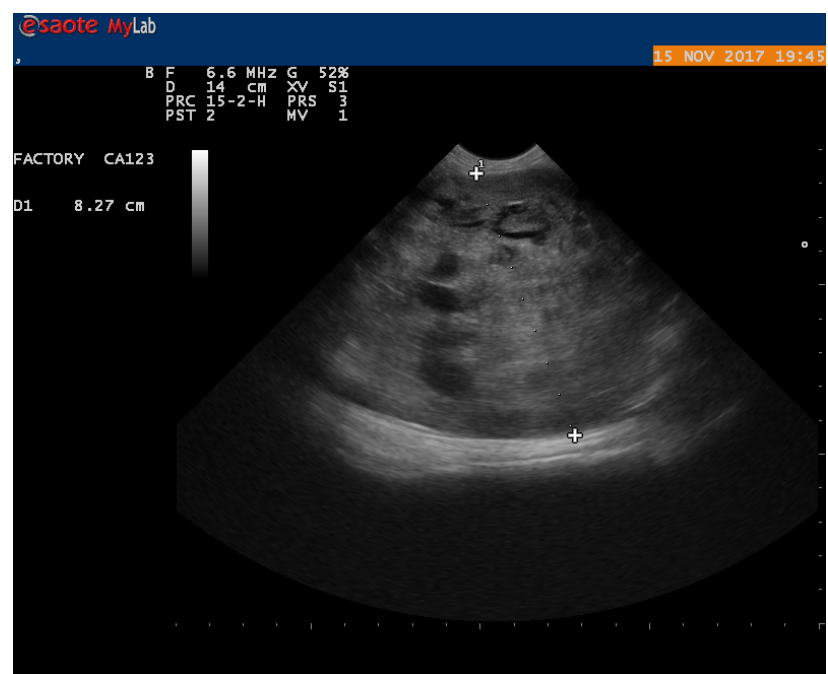

Рис. 10. Метастази мастоцитоми у селезінку. Щільне об'ємне утворення з вогнищами некротичного розпаду та псевдокистозної дегенерації

За проведення короткодинамічних сонографічних досліджень встановлено тенденцію швидкого поширення метастазійного процесу, свідченням цьому було виявлення нових осередків та збільшення у розмірах уже наявних.

Підсумовуючи результати проведених досліджень можна зробити висновок, що отримані дані доповнюють та розширюють знання щодо патогенезу мастоцитоми у собак, а також висвітлюють частоту поширенння та особливості перебігу даної онкологічної патології в умовах окремої географічної популяції України.

\section{Висновки}

1. Серед собак, що надійшли в клініки із хірургічними захворюваннями частка неоплазій займає у середньому $13,7 \%$ (10,56-14,93, у розрізі 20162020 років спостережень). У структурі онкологічних хвороб пухлині ураження шкіри становили 32,16 \%.

2. Мастоцитому шкіри діагностовано у 24 (18,75 \%) собак, віком від 4 до 16 років. Найвищі показники захворюваності встановлено поміж тварин віком від 8 до 11 років; при цьому медіана захворюваності становила 9,5 роки і мода - 9 років.
3. У розрізі порід шкірну мастоцитому встановлено в собак породи: ротвейлер - 4 випадки (16,7 \%), шарпей - 3 (12,5\%), стафордширський тер'єр - 3 (12,5\%), лабрадор - 2 (8,3\%), боксер - 2 (8,3\%), доберман 2 (8,3\%), чау-чау - 2 (8,3\%). Водночас, у тварин породи німецька вівчарка, алабай, спанієль, французький бульдог, мопс випадки захворювання були поодинокими (4,2 \%). Поміж хворих тварин пси становили $-54,2 \%$ і суки $-45,8 \%$.

4. Встановлено, що у 91,7 \% собак мастоцитоми були поодинокими і лише у 8,3 \% випадках - множинні. Найбільш частим місцем локалізації таких неоплазій були: тулуб (45,8\%), кінцівки (37,5%), рідше голова і шия, пахвова, пахвинна та промежинно-перианальна ділянки (16,7 \%).

5. У понад $87 \%$ випадках характерними ознаками мастоцитоми були: набряк та запалення як у самій пухлині, так і в навколишніх тканинах, алопеція над пухлиною, еритема та наявність виразок шкіри, періодична флуктуація величини пухлинного вузла, болючість при пальпації та свербіж шкіри в ділянці пухлини.

6. Інфільтративно вузловий та дифузно інфільтративний типу рентгенологічної візуалізації мастоцитом характеризує процес їх малігнізації.

7. Сонографічна візуалізація солідних гіперваскулярних вогнищ з центральним типом васкуляризації, на тлі дифузної інфільтрації неоплазії в глибшележачі шари шкіри та підшкірну клітковину, за вираженої перинодулярної запальної реакції навколишніх тканин є ознакою малігнізації мастоцитоми.

\section{References}

Akin, C. (2020). Mastocytosis: A Comprehensive Guide. Springer Nature, Switzerland AG. 307 p. doi: 10.1007/978-3-030-27820-5.

Akin, C., Valent, P., \& Metcalfe, D. D. (2010). Mast cell activation syndrome: Proposed diagnostic criteria. J Allergy Clin Immunol, 126(6), 1099-1104.e4. doi: 10.1016/j.jaci.2010.08.035.

Alvarez-Twose, I., Jara-Acevedo, M., Morgado, J. M., Garcia-Montero, A, Sanchez- Munoz, L., Teodosio, C., et al. (2016). Clinical, immunophenotypic, and molecular characteristics of well-differentiated systemic mastocytosis. J Allergy Clin Immunol, 137(1), 168-178. doi: 10.1016/j.jaci.2015.05.008.

Bautista-Quach, M. A., Booth, C. L., Kheradpour, A., Zuppan, C. W., Rowsell, E. H., Weiss, L., \& Wang, J. (2013). Mast cell sarcoma in an infant: a case report and review of the literature. J Pediatr Hematol Oncol, 35(4), 315-320. doi: 10.1097/MPH.0b013e318279e392.

Beer, P., Pozzi, A., Rohrer Bley, C., Bacon, N., Pfammatter, N. S., \& Venzin, C. (2018). The role of sentinel lymph node mapping in small animal veterinary medicine: A comparison with current approaches in human medicine. Vet Comp Oncol, 16(2), 178-187. doi: 10.1111/vco.12372.

Blackwood, L. (2011). Manual of Canine and Feline Oncology. BSAVA Manual of Canine and Feline Oncology. doi: 10.22233/9781905319749.12. 
Blackwood, L., Murphy, S., Buracco, P. et al. (2012). European consensus document on mast cell tumours in dogs and cats. Vet Comp Oncol, 10(3), e1-e29. doi: 10.1111/j.1476-5829.2012.00341.x.

Dobson, J. M. (2013). Breed-predispositions to cancer in pedigree dogs. ISRN Vet Sci., 2013, 941275. Epub 2013/06/06. doi: 10.1155/2013/941275.

Frieri, M., \& Quershi, M. (2013). Pediatric Mastocytosis: A Review of the Literature. Pediatr Allergy Immunol Pulmonol, 26(4), 175-180. doi: 10.1089/ped.2013.0275.

Frolova, T. V., Tereshchenkova, I. I., \& Stenkova, N. F. (2018). Mastotsytoz u praktytsi simeinoho likaria. Skhidnoievropeiskyi zhurnal vnutrishnoi ta simeinoi medytsyny, 1(8), 22-26. doi: 10.15407/internalmed 2018.01.022 (in Ukrainian).

Garden, O. A., Volk, S. W., Mason, N. J., \& Perry, J. A. (2018). Companion animals in comparative oncology: One Medicine in action. The Veterinary Journal, 240, 6-13. doi: 10.1016/j.tvj1.2018.08.008.

Gargiulo, G. (2018). Next-Generation in vivo Modeling of Human Cancers. Front. Oncol., 8, 429. doi: $10.3389 /$ fonc. 2018.00429 .

Garrett, L. (2014). Canine mast cell tumors: diagnosis, treatment, and prognosis. Vet Med (Auckl), 2014(5), 49-58. doi: 10.2147/VMRR.S41005.

Grüntzig, K., Graf, R., Hässig, M., et al. (2015). The Swiss Canine Cancer Registry: a retrospective study on the occurrence of tumours in dogs in Switzerland from 1955 to 2008. J Comp Pathol, 152(2-3), 161171. doi: 10.1016/j.jcpa.2015.02.005.

Gülen, T., Hägglund, H., Dahlén, B, \& Nilsson, G. (2016). Mastocytosis: the puzzling clinical spectrum and challenging diagnostic aspects of an enigmatic disease. Journal of International Medicine, 379(3), 211-228. doi: 10.1111/joim.12410.

Hartmann, K. et al. (2016). Cutaneous manifestations in patients with mastocytosis: Consensus report of the European Competence Network on Mastocytosis; the American Academy of Allergy, Asthma \& Immunology; and the European Academy of Allergology and Clinical Immunology. J Allergy Clin Immunol, 137(1), 35-45. doi: 10.1016/j.jaci.2015.08.034.

Hsu, F. I., \& Boyce, J. A. (2009). Biology of mast cells and their mediators. In: Adkinson Jr N. F., Busse W. W., Bochner B. S., Holgate S. T., Simons F. E. R., Lemanske Jr R. F., editors. Middleton's allergy: principles \& practice. 7 th ed. Philadelphia: Mosby/Elsevier, 311-328.

Ivashkiv, B. B., Mysak, A. R., Khomyn, N. M., \& Pritsak, V. V. (2019). Monitorynh poshyrennia spontannykh neoplazii u sobak v umovakh $\mathrm{m}$. Lviv ta $\mathrm{v}$ prymiskii zoni oblasnoho tsentru. Naukovyi visnyk veterynarnoi medytsyny. Zbirnyk naukovykh prats, 2(152), 97-104. doi: $\quad 10.33245 / 2310-4902-2019-152-2-97-104$ (in Ukrainian).

Leguit, R., Hebeda, K., Kremer, M., van der Walt, J., Gianelli, U., Tzankov, A., \& Orazi, A. (2020). The Spectrum of Aggressive Mastocytosis: A Workshop Report and Literature Review. Pathobiology, 87, 219. doi: 10.1159/000504099.
Lieshchova, M. O. Shuleshko, O. O., \& Balchuhov, V. O. (2018). Poshyrennia i struktura novoutvoren tvaryn u misti Dnipro. Naukovo-tekhnichnyi biuleten Naukovo-doslidnoho tsentru biobezpeky ta ekolohichnoho kontroliu resursiv APK, 6(2), 30-37 (in Ukrainian).

Lisickaja, K. V., \& Sedov, S. V. (2011). Mastocitoma sobak: jetiologija, klinika, diagnostika i lechenie. VetPharma, 3-4, 94-99 (in Russian).

Misdorp, W. (2004). Mast cells and canine mast cell tumours. A review. Veterinary Quarterly, 26(4), 156169. doi: 10.1080/01652176.2004.9695178.

Murphy, S., Sparkes, A. H., Blunden, A. S., Brearley, M. J., \& Smith, K. C. (2006). Effects of stage and number of tumours on prognosis of dogs with cutaneous mast cell tumours. The Veterinary Record, 158(9), 287291. doi: 10.1136/vr.158.9.287.

Mykhailenko, N. I., \& Voitsekhovych, D. V. (2017). Orhanna lokalizatsiia pukhlyn u dribnykh tvaryn riznykh vydiv. Naukovyi visnyk LNUVMtaBT imeni S.Z. Gzhytskoho, 19(77), 162-165. doi: 10.15421/nvlvet7735 (in Ukrainian).

Mysak, A. R. (2012). Problema neoplazii u produktyvnykh i dribnykh domashnikh tvaryn. Naukovyi visnyk LNUVMtaBT imeni S. Z. Gzhytskoho, 14, 2(52), 250-255. URL: https://nvlvet.com.ua/index.php/journal/issue/view/37/ 37 (in Ukrainian).

Okhotnikova, O. M., Sharikadze, O. V., \& Hryshchenko, O. M. (2018). Syndrom aktyvatsii mastotsytiv: suchasnyi pohliad na problemu. Klinichna imunolohiia. Alerholohiia. Infektolohiia, 2(107), 6-14 (in Ukrainian).

Owen, L. N. (1980). TNM Classification of Tumors in Domestic Animals. Geneva: World Health Organization.

Pardanani, A. (2016). Systemic mastocytosis in adults: 2017 update on diagnosis, risk stratification and management. American Journal of Hematology, 91(11), 1146-1159. doi: 10.1002/ajh.24553.

Shoop-Worrall, S., Marlow, S., Church, D., English, K., McGreevy, P., Stell, A., Thomson, P., O'Neill, D., \& Brodbelt, D. (2015). Prevalence and risk factors for mast cell tumours in dogs in England. Canine Genetics and Epidemiolgy, 2, 1. doi: 10.1186/20526687-2-1.

Sledge, D. G., Webster, J., \& Kiupel, M. (2016). Canine cutaneous mast cell tumors: A combined clinical and pathologic approach to diagnosis, prognosis, and treatment selection. Vet J., 215, 43-54. doi: 10.1016/j.tvj1.2016.06.003.

Smiech, A., Slaska, B., Lopuszynski, W., Jasik, A., Bochyńska, D., \& Dąbrowski, R. (2018). Epidemiological assessment of the risk of canine mast cell tumours based on the Kiupel two-grade malignancy classification. Acta Veterinaria Scandinavica, 60. doi: 10.1186/s13028-018-0424-2.

Tamlin, V. S., Bottema, C. D. K., \& Peaston, A. E. (2020). Comparative aspects of mast cell neoplasia in animals and the role of KIT in prognosis and treatment. Vet Med Sci, 6, 3-18. doi: 10.1002/vms3.201. 
Valent, P., Akin, C., Arock, M., et al. (2012). Definitions, criteria and global classification of mast cell disorders with special reference to mast cell activation syndromes: a consensus proposal. Int Arch Allergy Immunol, 157(3), 215-225. doi: 10.1159/000328760.

Valent, P., Akin, C., Hartmann, K. et al. (2017). Advances in the Classification and Treatment of Mastocytosis: Current Status and Outlook toward the Future. Cancer Res, 77(6), 1261-1270. doi: 10.1158/0008-5472.CAN-16-2234.

Valent, P., Sotlar, K., Sperr, W. R., Reiter, A., Arock, M., \& Horny, H. P. (2015). Chronic mast cell leukemia: a novel leukemia-variant with distinct morphological and clinical features. Leuk Res, 39(1), 1-5. doi: 10.1016/j.leukres.2014.09.010.

Villamil, J. A., Henry, C. J., Bryan, J. N., et al. (2011). Identification of the most common cutaneous neoplasms in dogs and evaluation of breed and age distri- butions for selected neoplasms. J Am Vet Med Assoc, 239 (7), 960-965. doi: 10.2460/javma.239.7.960.

Weishaar, K. M., Thamm D. H., Worley, D. R., \& Kamstock, D. A. (2014). Correlation of nodal mast cells with clinical outcome in dogs with mast cell tumour and a proposed classification system for the evaluation of node metastasis. J Comp Pathol, 151(4), 329-338. doi: 10.1016/j.jcpa.2014.07.004.

Willmann, M., Hadzijusufovic, E., Hermine, O. et al. (2018). Comparative Oncology: the Paradigmatic Example of Canine and Human Mast Cell Neoplasms. Veterinary and Comparative Oncology, 17(1), 1-10. doi: 10.1111/vco.12440.

Zon, H. A., Ivanovska, L. B., \& Dobia, M. V. (2013). Rezultaty diahnostyky pukhlyn sobak v m. Sumy. Visnyk Sumskoho natsionalnoho ahrarnoho universytetu. Seriia: Veterynarna medytsyna, 9, 171-174. URL: http://nbuv.gov.ua/UJRN/Vsna_vet_2013_9_53 (in Ukrainian). 